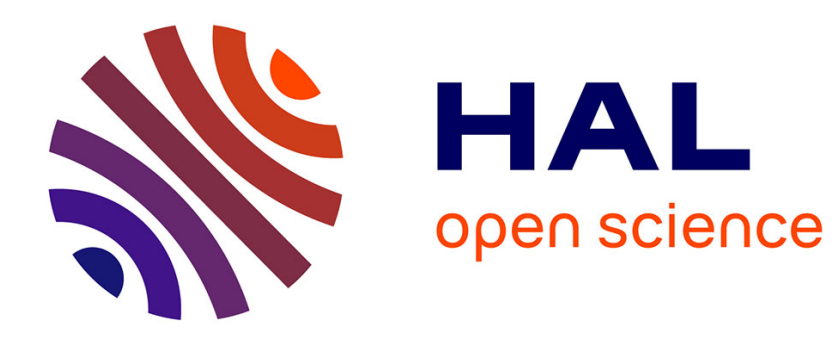

\title{
Conceptualizing circulation of knowledge in the social sciences
}

Wiebke Keim

\section{To cite this version:}

Wiebke Keim. Conceptualizing circulation of knowledge in the social sciences. Global knowledge in the social sciences. Made in circulation, Ashgate, pp.87-113, 2014, 978-1-4724-2617-8. halshs-01077347

\section{HAL Id: halshs-01077347 https://shs.hal.science/halshs-01077347}

Submitted on 24 Oct 2014

HAL is a multi-disciplinary open access archive for the deposit and dissemination of scientific research documents, whether they are published or not. The documents may come from teaching and research institutions in France or abroad, or from public or private research centers.
L'archive ouverte pluridisciplinaire HAL, est destinée au dépôt et à la diffusion de documents scientifiques de niveau recherche, publiés ou non, émanant des établissements d'enseignement et de recherche français ou étrangers, des laboratoires publics ou privés. 
Keim, Wiebke (2014): Conceptualizing circulation of knowledge in the social sciences. In: Keim, Wiebke; Çelik, Ercüment, Ersche, Christian, Wöhrer, Veronika (eds.): Global knowledge in the social sciences. Made in circulation. Farnham: Ashgate 2014: 87-113

- Manuscript -

Conceptualizing circulation of knowledge in the social sciences

Wiebke Keim

\section{Introduction:}

Circulation is not a new phenomenon - especially in the domain of science and knowledge. One would be hard pressed to think of a static and closed moment of knowledge production. Instead, exchange and circulation have always been constitutive of knowledge making and thus represent "both a fact of life and a usefully enabling condition of intellectual activity" (Said, 1983, p. 226). It is the use of the circulation-terminology that is recent, particularly with regard to South-North-circulation of knowledge. This paper attempts at conceptualizing circulation of knowledge, i.e. the overarching concept of this edited collection. I shall thus start with a brief historical overview over earlier frameworks for thinking the circulation of ideas in the (social) sciences prior to the introduction of this new concept, focusing mainly on international and South-North-circulation in accordance with the orientation of this edited collection.

\section{Import-export? The diffusionist model under scrutiny}

Modern science had long been considered an endogenous Western European creation, originating in the "scientific revolution" (16th-17th centuries). Science history has therefore often endeavored to explain the emergence of modern science out of the Western European experience on the basis of its supposed social, economic or cultural singularity (Raj, 2006, p. 1). Following the structure of the evolutionary stage model for modernization that Rostow presented in his anti-communist manifesto (Rostow, 1960), Basalla addressed the question of the world-wide diffusion ${ }^{1}$ of this supposedly endogenous European science:

"Three overlapping phases or stages constitute my proposed model. During 'phase 1' the nonscientific society or nation provides a source for European science. (...) 'Phase 2' is marked by a period of colonial science, and 'phase 3' completes the process of transplantation with a struggle to achieve an independent scientific tradition (or culture)" (Basalla, 1967, p. 611). Thus, in the first phase of scientific exploration, the non-European societies serve as sources of data, material and at best information - but not of (scientific) knowledge - that are collected and then processed in secluded, central places - the ideal type of the European laboratory. In the second phase of colonial dependency, colonists or

1 The meaning of the term "diffusionism" as used here in the context of history of science differs from its current usage in social anthropology. Cf. Kuklick (1996). 
assimilated elites favour the implementation of European science outside of Europe. Here, circulation refers to the worldwide diffusion of ready-made knowledge produced in Europe. The last phase consists in the establishment of independent, national scientific traditions based on Western standards: "If my analysis of phase 3 is correct, then we should find that the non-European nations, after a long period of preparation, have only recently approached the supremacy of Western Europe in science". Regarding the countries of the global South Basalla continues: "After several centuries of contact with European science the United States and the U.S.S.R. finally reached, and in some cases surpassed, the science of the Western European nations. This cannot be said of any other land outside of Western Europe." (Basalla, 1967, p. 620). The three-phase model is graphically represented in Figure 1 in: (Basalla, 1967,

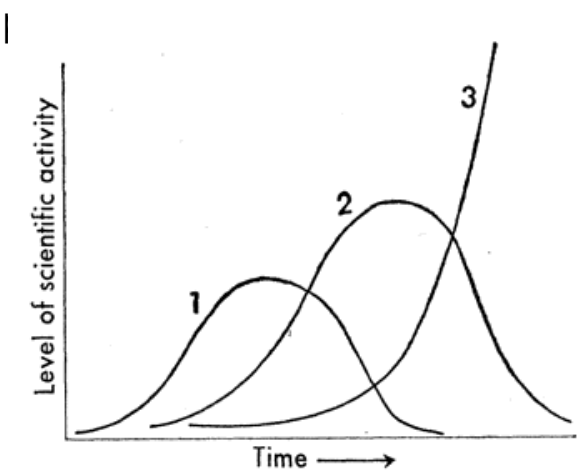

Fig. 1. Sequence of phases in the diffusion of Western science.

In the meantime, history of science has fiercely debated and negated this version of a mere unidirectional diffusion of European sciences into the "rest of the world". I will merely highlight the key arguments here2:

1) Criticism comprises, first of all, a fundamental questioning of the ethical and political values inherent to modern European sciences. These follow post-modern critiques of science as the "master narrative" of modernity and progress, and as a main instrument of western power and global hegemony. Instead, empirical investigations of the material, institutional, political and practical contexts and implications of modern scientific practice have questioned the very assumption of modern science as a purely logical, rigorous business independent of its social, economic and political contexts, and have located scientific knowledge production in precise moments and places.

2) Second, a determined move towards diversifying and historicizing the European tradition has pointed to a variety of diverging and competing national traditions and inner-European controversies ${ }^{3}$.

3) Following critiques of modernity as a genuinely endogenous European achievement, historians of science make it clear that modern science is not a purely endogenous European project either. Instead, under the heading of "colonial science", they have studied the interaction between distinct actors among the colonizers and the colonized, shaping these very categories in their encounters ${ }^{4}$. Each of them with their own political and knowledge-agendas have negotiated differently the influence of European science outside Europe and the responses and contestations on the ground. They have furthermore highlighted the unacknowledged contributions of non-European cultures to the making of this

\footnotetext{
2 Cf. the first chapter in Raj (2006) for a more detailed overview.

${ }^{3}$ For the social sciences, see Connell (2007); Steinmetz (2006); Zimmerman (2006).

${ }^{4}$ For a representative example of this current, cf. Petitjean, Jami, and Moulin (1992).
} 
supposedly European science. This has led to the assumption of a co-construction not only of Empire but of imperial science as well (Raj, 2006, p. 7).

4) Influenced by advances in global and entangled history (Kocka, 2003, p. 42), the former focus on fixed places of knowledge production has shifted towards concentrating on movements as sites of knowledge creation. This approach abandons the conceptual separation of the place and moment of collection of data and materials, of their processing and of their diffusion by challenging the very idea that objects, information and knowledge are "immutable and combinable mobiles" taken in undistorted form through paper and print culture from one place to another (Raj, 2006, pp. 225-226). Instead, for Raj it is "precisely the mutable nature of the materials - of the men themselves and of the knowledges and skills which they embodied - as also their transformations and reconfigurations in the course of their geographical and/or social displacements, that the focus on circulation helps bring to the fore" (Raj, 2006, pp. 20-21)

\section{A commitment to the circulation-idea for the history and present of the social sciences}

After the demise of diffusionism in current history of science, we are left with various perspectives that can be useful for analysing the historical and current interaction between European and non-European social sciences. These perspectives, from an early problematization of "traveling theory" (Said 1983) onwards variously named "international circulation of ideas" (Bourdieu, 2002; Sapiro \& Heilbron, 2002), "transnational science history" (Heilbron, Guilhot, \& Jeanpierre, 2008), "cosmopolitanism" (Beck \& Sznaider, 2006) etc. are partly written as direct responses and critiques to one another (notably Guilhot's critique of Bourdieu in this volume, see also below). My argument is that instead of trading one of these approaches against the other, we can imagine them as conceptualizations of different configurations of circulation. This paper thus puts the existing approaches into perspective with certain differentiation and qualification, to account for different types of interaction and exchange in the social sciences. I will thus not present them as alternatives or as a succession towards an ever better conceptualization of "circulation", but as variants under an overarching commitment to the circulation idea.

1) This overarching commitment to the circulation-idea means, first of all, an overall acknowledgement of the validity of critiques of diffusionism as the single globally valid model of circulation, critiques on which further conceptual work can build. Having said this, the idea of unilateral transmission as well as of centres and peripheries inherent in diffusionism are taken up again below.

2) Moreover and second, circulation refers to the fundamental idea that we cannot imagine social science knowledge-production to happen in closed, incommunicado places. It is always a collective endeavour and thus necessarily includes exchange between individual researchers. It seems appropriate, as Secord suggests, to "think about knowledge-making itself as a form of communicative action" and "give interaction between agents a central role in epistemology. Questions of trust, testimony, and communitarian objectivity are simultaneously questions of how knowledge travels, to whom it is available, and how agreement is achieved." (Secord 2004, pp.660-661). This means furthermore, "thinking always about every text, image, action, and object as the trace of an act of communication, with receivers, producers, and modes and conventions of transmission" (Secord, 2004,

\footnotetext{
${ }^{5}$ He refers to Latour's proposition on "immutable and combinable mobiles", Latour (1986, pp. 223; 227).
} 
p. 661). We will need to think about how this requirement can be respected within the domain of SouthNorth-circulation of knowledge in the social sciences.

3) Third, the idea of circulation acknowledges that it is difficult, in the social sciences, to determine with absolute certainty a clearly identified historical, cultural or institutional origin. Rather, circulation assumes that social science knowledge emerges out of contested and negotiated social, cultural, economic and academic contexts. Given social science works by individual authors, however novel and innovative, are rather to be understood as singular crystallizations, syntheses or refutations of broader social and academic debate (Sarasin \& Kilcher, 2011, pp. 9-10). Furthermore, key concepts in the social sciences are often metaphorically taken over from everyday language or other scientific fields ${ }^{6}$.

Building on these basic assumptions and on an extensive literature review including different and often disparate writings on circulation of ideas and knowledge, I will in the following present three different types of knowledge circulation in the social sciences: reception, exchange and negotiation of theory and practice. I assume this typology covers all relevant configurations of knowledge circulation in the social sciences in as far as traceable sequences of circulation are concerned. This paper excludes from its conceptualizing effort the infinite cases of broader, more complex, large scale, multidirectional, often unacknowledged or implicit and long-term circulations that are more difficult to grasp methodologically and conceptually, and to disentangle empirically. Scott has suggested speaking about "reverberations" as another metaphor for "echoes" or "influences" (Scott, 2002). The proposed typology will be useful in order to apprehend a maximum of relevant factors in empirically studying given traceable cases of circulation and to orient the analyst's view.

\section{The national, the central and the peripheral in circulation of knowledge}

The proposed typology seeks to overcome the limitations of existing conceptualizations. Bourdieu's "international circulation of ideas" (Bourdieu, 2002, p. 7), a rather simplistic attempt if measured by the standards of the author himself, lends itself as a starting point for critique and development of an alternative take on the phenomenon. The first issue around Bourdieu's approach that needs to be addressed is his exclusiveness in taking the fields of production and reception as national ones. Thus, the international is conceptualized as an extension of the national, the national precedes the international (Kauppi, 2011). Furthermore, the national is taken as an equivalent for a linguistic context, which also does not always apply - some national contexts are multilingual while many languages are cross-nationally used, and academic languages do not necessarily overlap with spoken and official languages of a given country. For sure, the nationality of contexts heavily impacts upon academic communication structures, despite tendencies of denationalization and transnational processes, internationalization and globalization ${ }^{7}$. But other frames of reference need to be taken into account, apart from the national and linguistic ones: regional or continental fields with their linguistic characteristics and supranational forms of institutionalization and funding; transnational networks; institutional contexts and established schools; cosmopolitan places; and cultural formations as frames of

\footnotetext{
${ }^{6}$ See Maasen (1995); Schlechtriemen's analysis of the organism- and network-metaphors as models for thinking society Schlechtriemen (2008), Schlechtriemen (2012); for concept-transfers between disciplines, see Stengers (1987); Bal (2002).

7 The majority of academic institutions with related legal frameworks, funding opportunities, employment structures, teaching curricula, publication sectors, diplomas and degrees as well as the main units of analysis in many social scientific fields remain national (see my more detailed argument in Keim (2008, pp. 29-32)).
} 
reference, as units of analysis and as fields of social and political practice. The following conceptualization cannot cover all of them with the same attention to detail but tries to acknowledge their importance.

More importantly, Bourdieu exclusively takes national contexts as "deforming prisma" ("prisme déformant"), in as far as they impose certain nationally formed "categories of perception and thought". Because of the gaps between the two contexts, reception processes are the domain of polemic, mutual misunderstanding and condemnation (Bourdieu, 2002, p. 7). This argument assumes that the national contexts in question exist independently of one another prior to the circulation; that they are not substantively altered by the circulation; and that the circulation occurs between national contexts that coexist at an equal footing.

The following argues against these assumptions in focusing on circulation of knowledge between actors and locations that do not enjoy the same prestige internationally, i.e. circulation that crosses over structural hierarchies. A strong argument for circulation, especially exchange, as creating and fostering intellectual spaces beyond the national cannot start without a buffer against the liberal dream of unlimited open spaces of circulation beyond all borders and boundaries. Circulation always happens within given spaces ${ }^{8}$ and according to certain enabling mechanisms. However much it transforms them in the process, it depends on them in the first place. And they are highly asymmetric: "(..) transnational disciplinary spaces of exchanges remain fragile. They show a highly dissymmetrical structure, where Western countries, among them the United States in the first place, hold a hegemonic position" (Heilbron et al., 2008, p. 157).

I thus take up arguments asking for a critical attitude towards a "rhetoric of linkage and circulation as the overcoming of boundaries and restrictions, through which all this excitement appears positive for everyone involved" (Tsing, 2000, p. 332). Tsing warns us: "A focus on circulation shows us the movement of people, things, ideas, or institutions, but it does not show us how this movement depends on defining tracks and grounds or scales and units of agency" (Tsing, 2000, pp. 337-338) ${ }^{9}$. Instead, to write a „political history of the circulation of knowledge” also means to account for the "hindrances, detours, bottlenecks and blocades" (Sarasin \& Kilcher, 2011, p. 10, transl. wk).

This is an aspect that has remained underdeveloped in existing studies on circulation of knowledge, probably as a result of focusing on small-scale circulation between locations that communicated at a rather equal level: "In situations where domination and conquest are less obvious, the significance of communication and acting at a distance has been easier to miss. This has certainly been the case in many local studies (...) in which scientists are shown to interact with those immediately around them,

\footnotetext{
8 This is in line with Raj's argument that circulation and exchange do not mean abandonment of space. In his historical study of encounters between Europeans and Asians, Raj seeks to "ground the circulation of knowledge and knowledge-related practices in specific localities. (...) Indeed, it is one of the main contentions of this book that localities constantly reinvent themselves through grounding (that is, appropriating and reconfiguring) objects, skills, ideas, and practices that circulate both within narrow regional or transcontinental - and indeed global - spaces" Raj (2006, p. 21).

9 Tsing goes as far as arguing that "'Circulation' is in global rhetoric what the 'penetration' of capitalism was in certain kinds of Marxist world-systems theory: the way powerful institutions and ideas spread geographically and come to have an influence in distant places. The difference is significant; where penetration always evokes a kind of rape, a forcing of some people's powerful interests onto other people, circulation calls forth images of the healthy flow of blood in the body and the stimulating, evenhanded exchange of the marketplace" Tsing (2000, p. 336). While hers is an important hint to the issue of asymmetries and inequalities underlying circulation processes, I do not endorse her argument wholesome, as this would make us return to the diffusionist model.
} 
with other audiences and competing centers of practice remaining in the background. (...) Struggles for access and control, however, are always at stake in any form of communication: to make knowledge move is the most difficult form of power to achieve" (Secord, 2004, pp. 669-670). Since this edited collection focuses on circulation of knowledge at a global scale, especially in South-North and SouthSouth directions, these aspects appear much more clearly and need to be apprehended systematically.

I base the following arguments on the analytical distinction between centres and peripheries in the international social sciences, developed in Keim (2008; 2010b), where I distinguish between three dimensions of centre-periphery-structures: 1) the dimension of material and institutional infrastructures (developed/underdeveloped social sciences); 2) the dimension of conditions of existence and reproduction (autonomous/dependent social sciences); 3) and the dimension of international recognition and prestige (central/marginal social sciences). I argue here that the three dimensions affect circulation of knowledge between places that occupy unequal positions within the international social sciences.

1) Material differences represent one of the main factors hindering or distorting circulation. In the end, ideas do not circulate immaterially, but in the form of books, articles, data sets and documents ${ }^{10}$, or embodied through persons who need visa and flight tickets: their circulation costs money. The internet has not dematerialized exchange ${ }^{11}$. In addition, material and institutional infrastructures that enable flows of intellectual migrations, often reflect and indeed reinforce centre-periphery-differentials. The nature of academic connections between former colonies and metropoles are an obvious example. Emerging institutionalized South-South-networks counter those historically established connections and thus materially challenge centre-periphery-structures. What would require particular attention but cannot be dealt with here are those cases where academic boycotts (Haricombe, 1992), censorship and "economies of shortage" affect the whole of the academic domain, especially with regard to circulating knowledge, to the degree that "members of the local community have to control carefully the priority list of items to be smuggled in, and consequently to be accepted or resisted. Under these circumstances they may even have no intention, need or desire to put a particular idea/theory on the top of the list." (Smejkalova, 1995, no page numbers).

2) In peripheral social sciences, circulation may appear as fundamental in order to create those peripheral scholarly spaces, whether these are perceived as national ones or otherwise. This refers to the historical difficulty in establishing autonomous traditions (Alatas, 2003; Alatas, 2006b) that is common to many southern social science communities. The structure of dependent (national) academic fields, their categories of perception and thought might not so much deform circulating knowledge but rather depend on it in order to take shape in the first place. An aspect that would have to be developed more thoroughly is in how far circulation affects not only the knowledge practice of involved individuals but (re-)structures and (re-)organizes whole academic fields ${ }^{12}$.

3) Asymmetries in recognition and prestige and thus in the power to shape the academic landscape and to impose certain themes and perspectives, are the third major factor. How knowledge circulates

10 "You want to do historical research on the South East Asian region, but then the manuscripts are in Heidelberg" Baharuddin (2012).

11 Access to a series of internet resources depends on institutional affiliation and corresponding payment of subscription fees: "There is a problem of access. Many sources and texts are now on the internet, but it does not mean they are available for everybody. In many South East Asian universities then we do not have the password, and you need a password if you want to access them" Baharuddin (2012).

${ }^{12}$ See Maasen, 1995; Stengers, 1987 for reorganization due to inter-disciplinary circulation of concepts and metaphors; see Rodríguez Medina, 2010 for a conceptualization of boundary objects and their impact in peripheral academia; see also his contribution in this volume. 
globally is heavily affected by the commonly and collectively perceived differentials between central and marginal spaces and reinforces those perceptions. Also, in transnational spaces of exchange, we have to acknowledge the role of "gatekeepers, translators, and other intermediates" linked with the "lives of ideas" (Kauppi, 2011). Many of the specifications of the following typology with regard to circulation between central and peripheral social sciences refer to that third dimension of global asymmetries in recognition. Still, "asymmetry is not synonymous with onesidedness" (Daston, 2009, p. 298).

What will appear clearly from the following outline is that hierarchies and inequalities within the international community affect forms and modes of circulation and that chances to participate and engage in different forms of circulation are unequally distributed internationally.

\section{Reception}

The first type of circulation of knowledge is that of reception: A scholar takes up theories, methods or concepts from elsewhere and relates them to his or her work. "From elsewhere" and the "relating" to the receiving scholar's work both need qualification. Classical studies in reception history have focused mainly on the reception of works, e.g. in literature studies, that have been especially influential. They take the "original" as the (highly valued) measure and analyse in how far it influenced other (mainly national) domains. Special attention is being paid to misunderstandings and distortions encountered in the receiving field (Jurt, 2009) as well as to differences in "representation and institutionalization" (Said, 1983, p. 226). In the following, I take reception as a much more fundamental, actually quite ordinary feature of scholarly activity.

From former (Keim, 2008; 2009; 2010a; 2010c) and ongoing work, I may assume that reception is likely to happen in the following contexts:

1. Over time, i.e. when relating to ideas that originated in earlier periods. An exchange (see section 5) with such more ancient sources is not possible anymore.

2. Over (perceived) distance between the location of the scholar in question and the (perceived) origin of the knowledge taken up. I am mainly thinking of distance in terms of North-South-circulation of ideas where "distance" is actually quite relative. How much distance is perceived as distance, and how much "context" requires explanation and situating, is not actually an issue of de-facto geographical distance between locations, but very much related to centre-periphery-perceptions in the international scholarly community, i.e. an effect of power relations and international hierarchies between more prestigious places of knowledge production and the perceived periphery ${ }^{13}$. As soon as the (perceived) distance is bridged, either through communication or mobility, the reception might turn into an exchange, if the involved academics perceive each other as interesting discussion partners (for more on this aspect see 5).

3. Over disciplinary boundaries. This refers to the frequent practice of borrowing concepts (Bal, 2002; Stengers, 1987), metaphors (Maasen, 1995), methodology or theoretical assumptions from neighbouring fields or from other disciplines. While they appear useful or productive to the one who borrows them, there is either no (perceived) need or no mechanism to return something to the field of origin.

\footnotetext{
${ }^{13}$ See for an analysis of the perceived distance and centrality or marginality of New York, Delhi, Vienna and Bratislava,
} Wöhrer. 
4. Over institutional boundaries. This refers mainly to reception of debates that occur outside of academia in the scholarly domain on the one hand, to the popularization of scholarly contents on the other hand. Genuine exchange with non-academic domains remains rare ${ }^{14}$ and shall be dealt with below (section 6). When circulation from non-academic into academic fields happens as reception, scholars tend to conceive of the received knowledge as non-scientific, terming it local, popular, indigenous or endogenous, specialized, lay or everyday-knowledge, or even more simply as information, documents, material, data. Social scientific work then builds on top of this received knowledge, but does not engage in a dialogue on an equal footing. If reception across institutional boundaries happens in the other direction, i.e. popularization of social scientific knowledge for broader audiences either in direct contact or mediated through print or communication media, the underlying assumption is that the receiving audience is not qualified in order to respond, judge, question or challenge the received inputs (Shinn \& Whitley, 1985). Otherwise, the process under way is not a reception but a negotiation of theory and practice. Reception between different academic institutions representing different schools of thought is likely to turn into controversy (see below).

5. Across structural hierarchies in a top-down-direction. This refers to reception of ideas from prestigious spaces and scientific authorities in given fields by persons who are neither colleagues at an equal footing nor direct disciples who have a chance to engage in some form of exchange however hierarchical. With regard to South-North-relations within the social sciences, the "intellectual dependency" (Alatas, 2003; Hountondji, 1990) and "captive mind"-debates (Alatas, 1974) all refer to reception processes not only across geographical distance, but along top-down-hierarchical divides between prestigious places of knowledge-production and the periphery. In these configurations, the receiving part lacks visibility and scholarly authority. The author of the received knowledge might not be aware of its usage in a different context, or might not see necessity to respond and engage in exchange.

Beyond these five points, Bourdieu suggests another hypothesis: Reception is likely to occur between agents in structurally analogous positions in their respective national fields (Bourdieu, 2002). This, in accordance with Bourdieu's overall sociological framework, means that the reader who receives the text is likely to occupy a position that is structurally analogous to that of its author in the field of production. More precisely, this refers to "ideological affinities, similar intellectual styles, and converging agendas across national borders, which then function as a social infrastructure for the circulation of ideas" (Guilhot, 2011, p.4). I argue that this assumption is only valid for similarly structured (national) academic fields with an autonomous intellectual tradition (Alatas, 2006a; Alatas, 2006b; Keim, 2008), and even there the idea that the reception occurs in an autonomous pre-structured field whose structuring and the positioning of receiving authors remain untouched by the reception needs to be questioned. This is not only true for face-to-face encounters as in the following statement: "To the extent that a given scientific 'field' is made of patterned relations between differentiated positions and their holders, the international circulation of intellectual migrants or, to put it differently, the adjunction of new players to an existing field, changes the morphology, scope and operation of the field itself" (Guilhot, 2011 , p. 9). The adjunction of new knowledge similarly transforms the space where it is received - the examples of travelling metaphors and concepts given by Stengers (1987) and Maasen (1995) are a case in point: We need to think of reception much more dialectically.

In peripheral academic fields in particular, the structuring as such may depend upon or be heavily affected by certain reception processes, and it may be that the positioning of receiving authors, their intellectual styles and agendas are not necessarily independent and pre-figured but depend on their

\footnotetext{
${ }^{14}$ For the benefits of such practice cf. the second part in Keim, 2008 as well as Keim, 2011, for a more detailed analysis of such practice, see Çelik (2012).
} 
reception practice. Furthermore, such an assumption does not at all allow us to think about much more contested forms of circulation, where difficulties are related to the fact that precisely, no structurally analogous positions exist and the intellectual tradition is fundamentally opposed to positively receiving certain circulating knowledges. This is exemplified by accounts of how feminism was received in post1989 Eastern Europe, where "(...) precisely those traditions out of and within which many feminists work, posed obstacles to the traveling of feminist theories (not only those developed in the American academic context) to this part of Europe." (Smejkalova, 1995, no page numbers). Instead of particular positions facilitating circulation, Smejkalova highlights "tendencies to freeze meanings and build borders towards their movement in and out of certain spaces" (Smejkalova, 1995, no page numbers).

Recent approaches that draw on new insights from global and entangled histories as well as repeated emphasis on the agency of all participants, as opposed to the supposed passivity of reception, make this first type of circulation appear obsolete. However, I argue here that it is a certain type of circulation besides others and different from others that should not be neglected because of enthusiasm for alternative approaches. A critical remark imposes itself however. Reception processes should be understood as sequences in a broader and longer circulation process, out of which a limited time period and a selection of actors, practices and texts are isolated for detailed analysis (see the abovementioned remark on more complex configurations, or reverberations). It depends on thorough study of each observed case, especially of the infrastructure and mechanisms that enable the reception process, in order to determine whether the reception-type is the one that most adequately describes the given case, or whether the perspective needs to be expanded in order not to overlook what is actually a process of exchange. From exemplary cases, it will also become obvious that more often than not, particular receptions are embedded in broader intellectual configurations that need to be apprehended, probably rather as controversies or co-construction (see section 5) in order to ensure a comprehensive analysis of the given reception process. Actually, it may prove insufficient to ask whom and what is received by whom. Just as important is to ask, against what and whom this knowledge is received (IDES/CeDInCi, 2008).

Apart from the circumstances under which they are likely to occur, we can qualify the nature of reception-processes content-wise, i.e. with regard to how the receiving scholar establishes a relation between the received knowledge and her or his work. Reception can lead to acknowledgement, acceptance, modification or rejection of the received knowledge. The following outline of these four possible modes of reception shows that, established critiques of the passivity and lack of agency in unidirectional reception overlook that each mode implies agency of the "receiver". Furthermore, it will become obvious that reception is necessarily the most frequent type of circulation, as it constitutes not only everyday, routine business of any social science scholar, but also the first step in what might develop into an exchange. Only systematic studies in a globally oriented perspective could show at a more structural level what critiques of intellectual dependency and captive mind argue, namely that reception happens more often in North-South than in South-North direction; furthermore, that chances of engaging in genuine forms of exchange are unequally distributed within the international scholarly community.

1) Mere acknowledgement refers to the mentioning of names or concepts as "decorative additions" or "theoretical enclaves" (Schirmer, 2004, pp. 89 ff.) that have no fundamental impact on the receiving scholar's own work; as well as to mere enumeration, p.ex. within state-of-the-art chapters or paragraphs. Reception across time, where certain names have acquired the status of compulsory references, as well as ornamental reference to scientific authorities often take the form of mere acknowledgement. The practice of acknowledging the existence of given authors or texts is often not so much an epistemic move but related to publication and visibility strategies, in which unequal centre- 
periphery-relations are enacted in order to satisfy demands of editors, publishers, reviewers and intended audiences. These pragmatic logics might be detrimental to epistemic logics.

2) Acceptance means a positive affirmation of the received knowledge. It appears useful for the scholar's own work to directly include it into one's argument, it generates heuristic insight or analytical clarity on which one can build. Sometimes whole theoretical frameworks are taken up and applied elsewhere. Here again, chances to serve as a theoretical framework and thus to impose a certain perspective on others' work are unequally distributed. Nevertheless, acceptance as well includes a moment of agency in as far as "the application of a theory to a particular case requires that the entities under examination belong to the class of entities the theory refers to. This correspondence is not given in the facts but needs to be theoretically established". This task is not straightforward, but requires "certain decisions as to what should be taken into account in order to say that two given entities are similar or different. And these decisions are suggested neither by the empirical world nor by the theory that is being extended" (Abend, 2006, p. 12). The same can be said for reactualisation of historical concepts that are being applied to current phenomena. Here as well, at least hypothetically, similarity of objects has to be established (Koselleck, [1979] 1995, p. 128).

3) Modification refers to the use of received knowledge as starting points for critical, creative and productive adaptation, hybridization (see Rodríguez Medina in this volume) and development of additional alternatives. The received knowledge appears as partly useful but as insufficient or partly inadequate for the receiving scholar's work. This insufficiency or inadequacy creates a creative tension with potential for scholarly innovation. This innovation can be a rather conceptual and theoretical one aiming at modifying or hybridizing an existing approach with other perspectives. I assume that this theoretical modification is likely to happen e.g. within established schools of thought. With regard to reception over (perceived) distances, modification is likely to happen because of empirical, contextrelated inconsistencies: the required establishment of correspondence between entities, mentioned under 2) ("acceptance") could not be confirmed. The received theory does not apply to the scholars' context but needs to be adapted.

4) Rejection means that the received knowledge is responded to negatively. The author questions or denies its validity, utility, adequacy or underlying assumptions and premises. The literature also highlights rejection at a larger scale as the rejection of the complete theoretical approach of feminism by whole intellectual fields in Eastern Europe (Smejkalova, 1995). Critique in itself is an important domain within the social sciences and an elaborate rejection can be a task on its own. Furthermore, in more instrumental, solution-oriented and constructive endeavours, rejection yields innovative potential: the receiving scholar builds an argument in explicit opposition or develops alternatives in order to overcome the limitations of the received approach. Rejection is unlikely to happen over long periods of time or over disciplinary and institutional boundaries. Ideas originating in such rather distant contexts are hardly seen worthy elaborate rejection.

Distinguishing between these four modes overcomes the limitations of Bourdieu's "program for the study of international cultural relations" (Bourdieu, 2002, p. 3), more precisely his perception of "major distortions in the process of transfer". These distortions mainly occur, according to him, because "texts circulate without their context", i.e. they do not import with them their field of production. Those who receive the text thus reinterpret it in the light of their own context, the context of reception, which generates major misunderstandings (Bourdieu, 2002, p. 4). In highlighting this aspect of reception processes, Bourdieu upholds the idea of the primacy of the original as the only true version of a text, and of the context of its production as the only measure. The true meaning can only be recovered by replacing the text into its original context. The prestige of original text and context are measured in 
terms of their international influence, while in studying the reception beyond the original context, the main focus is on deficits and distortions (see Jurt, 2009, pp. 379-380; Guilhot in this volume). His main focus on misunderstandings is limiting for a sound study of reception. Said, in his defence of the role of the critic, had actually suggested a more nuanced take on the phenomenon of traveling theory, "(...) when it is elevated to a general principle, the idea that all reading is misreading is fundamentally an abrogation of the critic's responsibility. It is never enough for a critic taking the idea of criticism seriously simply to say that interpretation is misinterpretation or that borrowings inevitably involve misreadings. Quite the contrary: it seems to me perfectly possible to judge misreadings (as they occur) as part of historical transfer of ideas and theories from one setting to another"15.

The common point is certainly that the personal reading and understanding, possibly the translation, the selection of potentially useful elements out of a framework within which they were conceptualized and meant to take meaning, even if this appears as mere acknowledgement, as simple acceptance or wholesome rejection, has a modifying character. Instead of discrediting them as misunderstandings and distortions of the "original", adaptations and reinterpretations have to be acknowledged as forms of instantiation of a given text in a context out of which and for which it was probably not written. The usefulness and validity of critical and creative modifications cannot be measured exclusively against the original - they need to make sense.

\section{Exchange}

Exchange is a necessary requirement inherent to scientific activity as such, as it ensures what has been variously termed critical, intersubjective peer-control or communitarian objectivity within the scholarly community. Exchange happens in a bi- or multidirectional prolongation of a first movement of reception. More fundamentally, exchange does not refer to finalized, completed sets of knowledge like e.g. accomplished theoretical works that travel to another place and time and are taken up by readers who are possibly unaware of their authors, historical situatedness and conditions of production. Instead, the knowledge in question is constructed through exchange and the (perceived) distance between participating scholars appears reduced. The assumption of pre-existing academic fields that remain untouched by circulation of knowledge is still less tenable with regard to exchange, where the concerned field is co-constructed in the course of exchange.

To limit description and analysis to the reception-part of what is actually an exchange would remain an incomplete and erroneous account of circulation. To the empirical observer, scholarly exchange - as opposed to reception - appears as such because it happens in a rather condensed and concentrated time-span (within one generation), and usually within bounded spaces, i.e. either given places or platforms of exchange.

Interest in international scholarly exchange can build on recent impulses and conceptual tools from the study of "entangled histories," or "histoire croisée" (Kocka, 2003, p. 42). Postcolonial approaches have increased interest in aspects of mutual influencing and interconnected or entangled processes of co-

\footnotetext{
${ }^{15}$ He continues: "Lukács wrote for as well as in a situation that produced ideas about consciousness and theory that are very different from the ideas produced by Goldmann in his situation. To call Goldmann's work a misreading of Lukács, and then to go on immediately to relate that misreading to a general theory of interpretation and misinterpretation, is to pay no critical attention to history and to situation, both of which play an important determining role on changing Lukács' ideas into Goldmann's" Said (1983, p. 236-237).
} 
construction beyond the national (Gould, 2007, p. 766). Transnational perspectives in science history insist that local and national frameworks of intellectual life, instead of being self-contained, separate intellectual universes, and are better understood as being "embedded in transnational relations of various kinds" (Heilbron et al., 2008, p. 147), or put even more strongly, as "the local instantiations or the dialectal declensions" of single transnational intellectual projects in given cases. (Guilhot, 2011, p. 11). These new perspectives have enhanced changes of perspective beyond mere accounts of centre-periphery-relations in order to reveal the often unacknowledged contributions of supposedly passive, peripheral recipients of theories produced elsewhere. Instead of emphasizing differences and separation, between, for instance, Europe and the global South, "the attempt is to disaggregate and scale these monoliths, and to trace the plural nettings, interactions and affinities that ranged across global dimensions" (Manjapra, 2010, p. 7). Raj's history of science perspective adds a reflexive moment in arguing that in their encounters, "both Europeans and Asians are changed and new kinds of knowledge emerge from their interactions" (Daston, 2009, p. 298).

A precondition for any exchange process is first, that participants share a strong knowledge-interest, and second, that there are mechanisms that enable reciprocal awareness and recognition as either serious opponents or as research and discussion partners. It is the second of these two requirements that often complicates North-South-relations. Important features of exchange are the following:

1) Mobility and personal encounter of scholars. Obviously, exchange is facilitated by face-to-face presence with colleagues who would otherwise remain representatives of distant institutions. While scholars have always travelled throughout the history of science, from the turn of the twentieth century onwards, various institutional and funding arrangements increasingly facilitated individual travel ${ }^{16}$. To academic travel through institutional arrangements, we have to add the realities of émigrés and refugees (e. g. Fleck, 2007). Furthermore, the foundation of international scholarly organizations and institutions and their regular activities ${ }^{17}$ have accelerated and increased opportunities for international networking and exchange and thus contributed to the "denationalization of the social sciences" (Heilbron et al., 2008, p. 151). What complicates the assumed reality of national fields of scholarly activity still more fundamentally is the reality of individuals who are affiliated with institutions in more than one country continuously.

2) Interstitial positions. Guilhot hypothesizes that interstitial, half-marginal positions of scholars, who thus do not have the status of major representatives of their respective national fields, or even reject dominant trends in their home countries, are more predisposed to transnational exchange. This assumption is directly opposed to Bourdieu's idea of "nationalisms and imperialisms" dominating the international circulation of ideas but maintains the idea that circulation occurs between structurally analogous positions. I would qualify Guilhot's argument with an additional hypothesis: that interstitial positions further transnational exchange only between scholars of central locations. In the case of exchange across differentials, i.e. between central and peripheral locations or between peripheries, only key figures of peripheral scholarly communities who are highly visible either due to scholarly

\footnotetext{
${ }^{16}$ Such as e.g. signed agreements between academic institutions, or "institutions comprising an emerging national apparatus of cultural diplomacy" (American philanthropies, European cultural institutes like Alliances françaises, the British Council, the German Goethe Institute, etc.) Heilbron, Guilhot, and Jeanpierre (2008, p. 151). These have fostered "displacements of professors and researchers, first between Europe and the United States, and between all continents after World War II" Heilbron, et al. (2008, p. 151).

17 Such as organizing conferences and editing international publications, creating networks that give way to meetings in working groups, committees and conferences, and the accompanying ongoing exchange of emails, letters and draft texts. Heilbron, et al. (2008); Gross and Fleming (2011).
} 
achievements and seniority or due to institutional exposure (e.g. presidents of national associations) are likely to engage in exchange. Further empirical evidence would be needed, however, to test these hypotheses.

3) Communicational languages. Guilhot, in his case study of International Relations-theory, points out one crucial requirement for successful transnational co-construction: the polyglott nature of such endeavours, and in particular "the capacity to develop non-vernacular, communicational languages" (Guilhot, 2011, p. 33), that "allowed for extremely coherent forms of scientific thought and communication across and above national contexts." (Guilhot, 2011, pp. 25-26) . It could be argued that scholars from many former colonies enjoy a certain advantage in this respect in comparison to smaller European and non-European language communities, in as far as oftentimes the language of the former colonizer is used academically. Current use of English or French opens possibilities of exchange within broad intellectual communities.

4) Exchange may also affect frames of reference of the knowledge constructed through it. By frames of reference, I here mean the assumed collective experience onto which theorizing builds and for which it is intended to be valid: who or what forms this (supposed, imagined) collective? The anchoring of social theory in alternative frames of reference beyond the national sometimes explicitly problematizes the primacy of the national as the major frame of reference on the one hand; on the other hand, the explicit anchoring of social science approaches in particular frames of reference may criticize inadequate assumptions of universality. Examples are the political category of the "global South" that informs attempts to write not only indigenous sociologies (see the debate between Adésínà, 2002; Akiwowo, 1990, Akiwowo, 1999; Lawuyi \& Taiwo, 1990; Makinde, 1990), but also "Southern Theory" or "Theory from the South" (Connell, 2007; Comaroff \& Comaroff, 2012). Another case is the utopian idea of a religiously grounded Muslim Ummah in the "islamization of knowledge"-debate that constitutes a frame of reference in terms of a supranational, religious-cultural unity (see AbūSulaymān, [1982] 1995; Edipoğlu, 2008; Keim, 2012).

Under an overarching exchange-model, we can distinguish between two fundamental forms of exchange: controversy and co-construction. While co-construction enhances means of intersubjective control already during the research process, controversy as a form of open critique functions as peercontrol of results and research output and thus similarly furthers scientific advancement. Famous controversies have taken place amongst defendants of opposing theoretical, politico-ideological and epistemological orientations ${ }^{18}$. However, controversies in the international arena, apart from theoretical, epistemological, political and ideological differences, often contain major reference to "national" difference and simultaneously reinforce such perceptions ${ }^{19}$. Authors in international controversies are often situated and contextualized nationally, i.e. they are taken as representatives of a given national (in the case of central scholars) or cultural context (in the case of scholars from peripheral locations). This can be regarded either as a particularistic limitation to their theorizing, or as an insertion into given national scholarly traditions.

The most common type of co-construction is obviously collaboration of researchers who are located within the same institution and field of research, but also refers to intensive exchange between scholars from different locations. Guilhot's analysis of the transnational emergence of International Relationstheory, written as an explicit critique of Bourdieu's "import-export-model" for the international circulation

\footnotetext{
${ }^{18}$ For example the various famous controversies amongst German historians ("Historikerstreite") as well as the legendary "Positivismusstreit" (Adorno et al. [1969] 1993).

${ }^{19} \mathrm{Cf}$., for instance, the historical controversy between al-Afghani and Renan Schäbler (2007); Medrow (2012 and 2013).
} 
of ideas is a masterpiece in this respect (see in this volume). Another key example of the creation of a transnational intellectual space is presented in Wöhrer's critical account of transnational gender studies (Wöhrer). She integrates a concern for the transnational constitution of the field with a thorough analysis of the impact of centre-periphery-relations inside this transnational scholarly community.

The analytical distinction does not mean to disregard the fact that controversy, despite its confrontational character, has an aspect of co-construction in the sense that the process and resolution of a scholarly controversy usually leads to the advancement of knowledge at a more abstract level. Or that co-construction certainly includes controversial aspects as well.

\section{Negotiating theory and practice}

This section deals with exchange between academic and extra-academic audiences. In lack of a better terminological alternative, we call this third configuration "negotiating theory and practice". The term "transdisciplinarity" has been suggested in other contexts for interaction between academic and extraacademic domains (Wickson, Carew, \& Russell, 2006). I prefer to speak about a negotiation between theory and practice. While this choice of terminology evokes a strong opposition between the two that cannot be sustained in as far as doing theory is also a form of practice and practice is usually not devoid of theory ${ }^{20}$, I suggest it for various reasons: First of all, "transdisciplinarity" as a rather technical term does not evoke the idea of exchange, struggle, contestation and thus negotiation, i.e. the fact that if interaction happens between the two domains, it is usually around topics of relevance for both sides, where different logics and interests are at stake. "Transdisciplinarity" does not imply either to say anything about the quality of the negotiation. Furthermore, "transdisciplinarity" as a term forms part of a specialized, academic vocabulary that would probably not be used by extra-academic actors and audiences. Speaking about theory and practice, on the contrary, takes up rather common sense notions of what is done inside and outside of academia, in a division of work where both are recognized and legitimate and both respond to different (institutional) logics.

In opposition to the unilateralism of either collecting non-academic forms of knowledge as data or information on the one hand, or of popularizing scientific contents for an anonymous public on the other hand (Shinn \& Whitley, 1985), the negotiation between academic and extra-academic actors corresponds to a specific type of exchange. Whether rather controversial or rather co-constructive, it distinguishes itself by a different logic from purely academic forms of exchange. What mainly characterizes this third type of circulation is that the issues at stake are different from purely academic concerns. Negotiating theory and practice is animated "by the pragmatic need to get things" done when "disparate groups seek to solve problems together in order to address their pressing concerns" (Manjapra, 2010, p. 1). What is negotiated here is the practical, social, economic or political relevance of social science production on the one hand, and the implications of social experiences on the ground for theorizing on the other hand. Negotiating theory and practice means that academics need to take over responsibility for the results they feed into public debates, as these may serve as orientation for social action. On the other hand, the experience and knowledge of non-academic actors (with diverging degrees of social prestige $)^{21}$ and their responses to social science theorizing functions as a "reality-

\footnotetext{
20 Boaventura Sousa Santos has pointed out that all practices imply knowledge Sousa Santos, Boaventura de (2005).

21 The degree to which the response of social actors is taken seriously is related to their social status. For example, governments assign contract research, or even finance social science research institutes whose aim is political consultancy. Expert interviews with representatives of highly institutionalized organizations will be considered differently than actors in
} 
check" for the approaches and assumptions that scholars hold - a form of critique that has not found much attention in the theory, methodology and epistemology of the social sciences, where peer-control, i.e. an inner-scientific evaluation - whether called intersubjectivity or communitarian objectivity - is the predominant criterion for relevance, quality and validity.

Participatory action research could be mentioned as an exception or counter example in this regard. In mainstream sociology, however, it is more perceived as a particular methodological approach, significant as well for a specific ethical attitude, rather than with regard to its epistemic implications. This has been true until recently in Latin America as well, where participative action research started in the 1960ies, in the context of research with marginalized groups (Fals-Borda \& Rahman, 1991). The access to knowledge and education was considered as an important factor of marginalization, among others. Research was being conceived as a knowledge building practice that should directly benefit the people concerned in research projects. Though being conceived as a practice of solidarity, the research and knowledge construction was still considered to be the responsibility of the academic researcher (Freire, [1968] 2000). This division of labour is conserved in various strands of present day participative action research, where a varying degree of participation is being considered. However, the academic research projects with social movements like the Movimento Sem Terra in Brazil (Barbosa Pinheiro, 2011) and the Zapatista movement (Leyva \& Speed, 2008) has shown that with a growing degree of organization in social movements, knowledge production cannot be regarded the exclusive privilege of the academic researcher any more and both, researcher and the participants of social movements have to be regarded as subjects in the knowledge building process (Meckesheimer).

In my study on the historical emergence of South African labour studies (Keim, 2008; 2011), I insist on the particular interest of practicing a negotiation between theory and practice, i.e. socially relevant sociology, in a peripheral context. The move towards alternative audiences and arenas of competition has counter hegemonic potential as it weakens the recognition of and orientation towards central, prestigious arenas of competition. Engaging in dialogue with extra-academic actors - in that case the emerging black labour movement - and taking them, their lived experience and knowledge seriously, helped to develop a constructive, creative, experimental and solution-oriented attitude. Taking over responsibility for research results that would serve as an orientation for social and political action ensured committed, serious and rigorous scholarly work. The shortcomings of imported sociological approaches became quickly apparent empirically and the need to find constructive solutions generated a creative tension. This has led, over the years, to conceptual and theoretical innovations and to a not only socially relevant, but increasingly theoretically relevant sociology of labour.

Furthermore, historical studies reveal that it has often been through a negotiation of theory and practice that South-South-circulation of knowledge has developed historically, rather than out of purely academic concerns. Out of negotiation of theory and practice, broader intellectual configurations have created "shared transnational public spaces". A key example are the anti-colonial movements and the intellectual debates they generated in constant negotiation with political practice. Manjapra (2010, p. 1) conceptualizes it as a project of "aspirational cosmopolitanism", i.e. "the pursuit of conversations across lines of difference, between disparate socio-cultural, political and linguistic groups, that provisionally created shared public worlds. Translation, interpretation and shared social experience created heterogeneous transnational public space marked by irreducible incongruities of power and cultural values, yet also by a degree of shared dwelling". The intellectual networks underlying this project he

socially marginalized positions who, in many cases, tend not to be taken seriously as interlocutors but are rather seen in the role of informants. 
terms "cosmopolitan thought zones"22. Both represent an ethical counter-tendency to the simultaneous nationalist politics of the anti-colonial movements. The example is particularly interesting for our project in terms of its challenging of the North-South-divide by pointing to transnational networks across the global South that put into question the established "cartographic imagination" of East versus West and North versus South.

Devés Valdés (2011) has highlighted other early forms of South-South circulation through a negotiation of theory and practice. Not only political, emancipatory projects, but also religious and cultural inheritances had long circulated through transnational movements and ecumenes spanning large parts of the global South, like the theology of liberation, the Socialist International, the Third World Forum. A more recent example is the World Social Forum. These have given rise to a series of "-isms" that connect intellectual communities outside of the North-Atlantic: Ethiopism, Arielism, Pan-Islamism, Jadism, Slavophilia, Subalternism, Baazism, Thirdworldism, Conscientism, Cepalism, Arab Socialism, Negritude and Indigenism, to mention only a selection (Devés Valdés, 2012). Kott (2011a; 2011b) has exemplified how international organizations, in this case the International Labour Organization, can be analysed as platforms for the negotiation of theory and practice.

\section{Conclusion:}

This paper has synthesized recent debates that have led history of science away from a blunt diffusionist model as the only and globally valid version of historical knowledge circulation towards approaches informed by recent historical works on global entanglements and interconnections. Out of various, at times unconnected and disparate strands of debate inside the social sciences as well as in broader science and intellectual history, I have developed three types for different configurations of international circulation of knowledge, paying particular attention to circulation across centre-peripherystructures. The paper then outlined major characteristics of these types of circulation, like their preconditions, functioning, their possible effects on the circulating knowledge and some methodological implications for their study.

What this paper has not developed in detail is the issue of scales of analysis. The three types of circulation as outlined here refer to empirically observable, graspable circulations within a rather short timespan and in clearly delimited spaces, i.e. at a rather reduced scale, where in principle all participants, texts and objects involved could be taken into account. As soon as the analyst tries to account for more complex, long-term and widespread circulation phenomena, i.e. extending perspective in time and space, analytical clarity decreases in the same measure as scale and complexity increase. Most studies of circulating knowledge have focused on those "situations in which the distance between these elements [author, narrator, text, work, and readers, wk] is relatively limited and subject to convention." But "the further we move away from sites of the production of new knowledge, the vaguer our descriptive categories tend to become." (Secord, 2004, p. 662). To mention only a few points, a thorough analysis of such forms of circulation would need to take into account the mediation through teaching and secondary literatures, at best over generations; the constructions of traditions, schools and canons; silent circulation, i.e. implicit, unacknowledged or taken-for-granted referencing; translations

\footnotetext{
22 The author provides the following definition: "Cosmopolitan thought zones emerge from the aspiration to build conceptual and linguistic bridges, through acts of translation and interpretation, often between highly different and politically unequal social communities in order to work towards a perceived good" Manjapra (2010, p. 3).
} 
between various languages; a systematic mapping and timing of the wide spread of circulating objects; a thorough study of the multiple experiences and multiple meanings associated with the circulating knowledge. As these are empirically difficult, if not unfeasible tasks, literature has preferred to apprehend such phenomena, rather metaphorically, as reverberations (Scott, 2002).

To conclude, the studies in this volume, abandoning not only diffusionism but also simplistic and onesided understandings of circulation of knowledge, might help us improve the quality of sociology as an international discipline. Such an endeavour at collectively understanding international circulation of social science knowledge might help us, as Bhambra proposes, to "de-centre Europe in our considerations. We would need to recognize contributions made in connections of which Europe had no part, as well as connections suppressed in the history of European uniqueness. (...) The task now is a cosmopolitanism that can learn from others where we recognize that what 'they' contribute is not a confirmation of what 'we' already know, but the bringing into being of new understandings relevant to the worlds we inhabit together." (Bhambra, 2010, p. 43).

\section{References}

Abend, G. (2006). Styles of sociological thought: sociologies, epistemologies, and the Mexican and US quests for truth. Sociological Theory, 24(1), 1-41.

AbūSulaymān, ‘. (Ed.). ((1982) 1995). Islamization of knowledge series: 1 i.e. 2. Islamization of knowledge: General principles and work plan. Translation of Islamiyat al ma'rifah (3rd ed.). Herndon, Va., USA: International Institute of Islamic Thought; International Islamic Publishing House.

Adésínà, J. (2002). Sociology and Yoruba studies: epistemic intervention or doing sociology in the ,vernacular'? African Sociological Review, 6(1), 91-114.

Adorno, T. W., Albert, H., Dahrendorf, R., Habermas, J., Pilot, H., \& Popper, K. R. (Eds.). ([1969] 1993). Wissenschaft: Vol. 4620. Der Positivismusstreit in der deutschen Soziologie (Lizenzausg.). München: Dt. Taschenbuch-Verl.

Akiwowo, A. (1990). Contributions to the sociology of knowledge from an African oral poetry. In M. Albrow \& E. King (Eds.), Globalization, knowledge and society: readings from International Sociology (pp. 103-117). London.

Akiwowo, A. (1999). Indigenous sociologies - extending the scope of the argument. International Sociology, 14(2), 115-138.

Alatas, S. F. (2003). Academic dependency and the global division of labour in the social sciences. Current Sociology, 51(6), 599-613.

Alatas, S. F. (2006a). Alternative discourses in Asian social science. Responses to Eurocentrism. New Delhi u.a.O.: Sage Publications India.

Alatas, S. H. (1974). The captive mind and creative development. International Social Science Journal, XXVI(4), 691-700.

Alatas, S. H. (2006b). The autonomous, the universal and the future of sociology. Current Sociology, 54(1), 7-23.

Baharuddin, S. A. (2012, May). Beyond Methodology: Knowledge making on Southeast Asia. Conference: Methodology in Southeast Asian Studies: grounding research - mixing methods, Freiburg.

Bal, M. (2002). Travelling concepts in the humanities: A rough guide. Green College lectures. Toronto, Ont: University of Toronto Press. Retrieved from http://site.ebrary.com/lib/alltitles/docDetail.action?doclD=10218814 
Barbosa Pinheiro, L. (2011, November). Diálogos en Movimiento: reflexiones acerca de la praxis educativo-pedagógica, la producción de saberes y la génesis de una otra episteme y cultura política en el Movimiento de los Sin Tierra - MST. Seminario (Virtual) Internacional "Creación de Prácticas de Conocimiento desde elGénero, los Movimientos y las Redes". Retrieved from http://www.encuentroredtoschiapas.jkopkutik.org/index.php/es/lia-pinheiro-barbosa

Basalla, G. (1967). The Spread of Western Science: A three-stage model describes the introduction of modern science into any non-European nation. Science, Technology \& Society, 156(3775), 611-622.

Beck, U., \& Sznaider, N. (2006). Unpacking cosmopolitanism for the social sciences: a research agenda. The British Journal of Sociology, 57(1), 3-23.

Bhambra, G. K. (2010). Sociology after Postcolonialism: Provincialized Cosmopolitanisms and Connected Sociologies. In E. Gutiérrez Rodríguez, M. Boatcă, \& S. Costa (Eds.), Global connections. Decolonizing European sociology. Transdisciplinary approaches (pp. 33-48). Farnham, Burlington, VT: Ashgate.

Bourdieu, P. (2002). Les conditions sociales de la circulation internationale des idées: Conférence prononcée le 30 Octobre 1989 pour l'inauguration du Frankreichzentrum de l'Université de Fribourg. Actes de la Recherche en Sciences Sociales, 5(145), 3-8.

Çelik, E. (2012, August). The Role of Intellectuals in the Circulation of Knowledge in the South African Labour Movement, 1970s-1980s. Second ISA Forum of Sociology "Social Justice and Democracy", Buenos Aires.

Comaroff, J., \& Comaroff, J. L. (2012). Theory from the South: or, how Euro-America is evolving towards Africa. Boulder: Paradigm Publishers.

Connell, R. (2007). Southern theory. The global dynamics of knowledge in social science. Cambridge: Polity Press.

Daston, L. (2009). Book review: Kapil Raj, Relocating Modern Science: Circulation and the Construction of Knowledge in South Asia and Europe, 1650-1900. Houndmills and New York: Palgrave Macmillan, 2007. Pp. xiv+285. ISBN 978-0-230-50708. £53.00 (hardback). The British Journal for the History of Science, 42, 298-299.

Devés Valdés, E. (2011). El pensamiento africano Sudsahariano desde mediados del siglo XIX hasta la actualidad (1st ed.). Buenos Aires: Editorial Biblos.

Devés Valdés, E. (2012, July). Pensando el mundo en-desde el Sur. La circulación de las ideas y los puntos de encuentro entre la regiones periféricas: historia y actualidad: Keynote Address, University of Vienna.

Dotti, J. E. (Mayo 2008). Interview by IDES/CeDInCi. Buenos Aires.

Edipoğlu, K. (2008). Islamisierung der Soziologie oder Soziologisierung des Islam?: Indigenisierungsansätze in Malaysia, Iran und der arabischen Welt. Saarbrücken: VDM Verlag Dr. Müller.

Fals-Borda, O., \& Rahman, M. A. (1991). Action and knowledge: Breaking the monopoly with participatory action research. New York, London: Apex Press; Intermediate Technology Publications.

Fleck, C. (2007). Transatlantische Bereicherungen: Zur Erfindung der empirischen Sozialforschung (1. Aufl). Suhrkamp Taschenbuch Wissenschaft: Vol. 1823. Frankfurt am Main: Suhrkamp.

Freire, P. ([1968] 2000). Pedagogy of the oppressed (30th anniversary ed). New York: Continuum.

Gould, E. H. (2007). Entangled Histories, Entangled Worlds: The English-Speaking Atlantic as a Spanish Periphery. The American Historical Review, 112(3), 764-786. doi:10.1086/ahr.112.3.764

Gross, N., \& Fleming, C. (2011). Academic conferences and the making of philosophical knowledge. In C. Camic, N. Gross, \& M. Lamont (Eds.), Social knowledge in the making (pp. 151-180). Chicago, London: University of Chicago Press. 
Guilhot, N. (2011). French connections. Writing the history of international relations theory as a transatlantic discipline, Strasbourg ESF Workshop "International circulation of ideas".

Haricombe, L. J. (1992). The effect of an academic boycott on academics in South Africa (PhD Thesis). University of Illinois, Urbana-Champaign.

Heilbron, J., Guilhot, N., \& Jeanpierre, L. (2008). Toward a transnational history of the social sciences. Journal of the History of the Behavioral Sciences, 44(2), 146-160.

Hountondji, P. J. (1990). Scientific dependence in Africa today. Research in African Literatures, 21(3), $5-15$.

Ibn Khaldun. (1967-68). Discours sur l'Histoire universelle Al-Muqaddima (Monteil, Vincent). Beyrouth: Sindbad.

Jurt, J. (2009). Transnationale Literatur-Rezeption Am Beispiel der Aufnahme Jean-Luc Benoziglios im deutschsprachigen Raum. arcadia, 44(2).

Kauppi, N. (2011, November). The Geopolitics of Ideas. The Circulation of Knowledge and Power in Europe and North America. European Science Foundation Exploratory workshop: "The Geopolitics of Ideas: The Circulation of Knowledge and Power in Europe and North America", Strasbourg.

Keim, W. (2008). Vermessene Disziplin.: Zum konterhegemonialen Potential afrikanischer und lateinamerikanischer Soziologien. Univ., Diss.--Freiburg, 2006. Global studies. Bielefeld: transcriptVerl.

Keim, W. (2009). Social sciences internationally - the problem of marginalisation and its consequences for the discipline of sociology. African Sociological Review, 12(2), 22-48.

Keim, W. (2010a). Analyse des invitations de chercheurs étrangers par l'EHESS: Compétences reconnues et clivages Nord-Sud. Cahiers de la Recherche sur l'Education et les Savoirs, (9).

Keim, W. (2010b). Aspects problématiques des relations internationales en sciences sociales: pour un modèle centre-périphérie. Revue d'Anthropologie des Connaissances, 4(3), 570-598.

Keim, W. (2010c). The internationalisation of social science: distortions, dominations and prospects. In International Social Science Council (Ed.), World Social Science Report 2010 (pp. 169-171). Paris: Unesco Publishing.

Keim, W. (2011). Counter hegemonic currents and internationalization of sociology. Theoretical reflections and one empirical example. International Sociology, 26(1), 123-145.

Keim, W. (2012, June). Islamization of Knowledge in Sociology: Between Western Approaches, Culture and Traditional Islamic Scholarship, Istanbul.

Kocka, J. (2003). Comparison and Beyond. History and Theory, 42(1), 39-44.

Koselleck, R. ((1979) 1995). Vergangene Zukunft: Zur Semantik geschichtlicher Zeiten (3. Aufl.). Suhrkamp-Taschenbuch Wissenschaft: Vol. 757. Frankfurt am Main: Suhrkamp.

Kott, S. (2011a). Les organisations internationales - terrains d'étude pour une histoire globale. Zeithistorische Forschungen/Studies in Contemporary History, 8(3). Retrieved from http://www.zeithistorische-forschungen.de/16126041-Kott-3-2011\#fr

Kott, S. (2011b). Les organisations internationales, terrains d'étude de la globalisation: Jalons pour une approche socio-historique. Presses de Sciences Po | Critique internationale, 52(2), 9-16. Retrieved from http://www.cairn.info/revue-critique-internationale-2011-3-page-9.htm

Kuklick, H. (1996). Diffusionism. In A. Barnard \& J. Spencer (Eds.), Encyclopedia of social and cultural anthropology (pp. 243-245). London, New York: Routledge.

Latour, B. (1986). Science in action: how to follow scientists and engineers through society: Open University Press.

Lawuyi, O. B., \& Taiwo, O. (1990). Towards an African sociological tradition: a rejoinder to Akiwowo and Makinde. In M. Albrow \& E. King (Eds.), Globalization, knowledge and society: readings from International Sociology (pp. 135-151). London. 
Leyva, X., \& Speed, S. (2008). Hacia la investigación descolonizada: nuestra experiencia de co-labor. In X. Leyva, A. Burguete, \& S. Speed (Eds.), Gobernar (en) la diversidad: experiencias indígenas desde América Latina. Hacia la investigación de co-labor (pp. 65-107). México: CIESAS, FLACSOEcuador y FLACSO-Guatemala.

Maasen, S. (1995). Who is afraid of metaphors. In S. Maasen, E. Mendelsohn, \& P. Weingart (Eds.), Sociology of the sciences yearbook: XVIII. Biology as society, society as biology: metaphors (pp. 1136). Dordrecht/Boston/London: Kluwer.

Makinde, A. A. (1990). Asuwada principle: an analysis of Akiwowo's contributions to the sociology of knowledge from an African perspective. In M. Albrow \& E. King (Eds.), Globalization, knowledge and society: readings from International Sociology. London.

Manjapra, K. (2010). Introduction. In S. Bose \& K. Manjapra (Eds.), Palgrave Macmillan transnational history series. Cosmopolitan thought zones. South Asia and the global circulation of ideas (pp. 119). Basingstoke: Palgrave MacMillan.

Meckesheimer, A. La memoria colectiva como acción social. Reflexiones a partir del acompañamiento de una sistematización de experiencias de la Coordinación de Mujeres de la Diócesis de San Cristóbal de las Casas, Chiapas. Seminario (Virtual) Internacional "Creación de Prácticas de Conocimiento desde elGénero, los Movimientos y las Redes". Retrieved from http://www.encuentroredtoschiapas.jkopkutik.org/index.php/es/anika-meckesheimer

Medrow, L. (2012, March). Islam and modern science theory - an international fundamental debate, 1883-1885. Journée d'Etudes "Paramètres épistémologiques de la circulation des idées en sciences sociales", Freiburg.

Medrow, L. (2013). Der Islam und die Wissenschaft - Die globale Medialisierung der Debatte im Streit um Ernest Renan und Ğamāl ad-Dīn al-Afǵānī.

Petitjean, P., Jami, C. J., \& Moulin, A. M. (1992). Science and empires - histoire comparative des échanges scientifiques - expansion européenne et développement scientifique des pays d'Asie, d'Afrique, d'Amérique et d'Océanie. Dordrecht: Kluwer.

Raj, K. (2006). Relocating modern science: Circulation and the construction of scientific knowledge in South Asia and Europe ; seventeenth to nineteenth centuries. Delhi: Permanent Black.

Rodríguez Medina, L. (2010). Centres and Peripheries in Political Science: The Case of Argentina (PhD Thesis). Saint Catharine's College, University of Cambridge, Cambridge.

Rostow, W. W. (1960). The stages of economic growth: a non-communist manifesto. Cambridge: Cambridge Univ. Press.

Said, E. W. (1983). Traveling theory. In The world, the text, and the critic, pp. 226-247, Cambridge: Harvard University Press.

Sapiro, G., \& Heilbron, J. (2002). La circulation internationale des idées. Actes de la Recherche en Sciences Sociales, 145(décembre).

Sarasin, P., \& Kilcher, A. B. (2011). Editorial. In D. Gugerli, M. Hagner, C. Hirschi, A. B. Kilcher, P. Purtschert, P. Sarasin, \& J. Tanner (Eds.), Nach Feierabend. Zürcher Jahrbuch für Wissensgeschichte: Vol. 7. Zirkulationen (pp. 7-11). Zürich: Diaphanes.

Schäbler, B. (2007). Religion, Rasse und Wissenschaft. Ernest Renan im Disput mit Jamal al-Din alAfghani. Retrieved from http://www.europa.clio-online.de/2007/Article=274

Schirmer, D. (2004). Soziologie und Lebensstilforschung in der Volksrepublik China: Perspektiven einer Mikrotheorie gesellschaftlichen Wandels. Sozialtheorie. Bielefeld: Transcript.

Schlechtriemen, T. (2008). Metaphern als Modelle: Zur Organismus-Metaphorik in der Soziologie. In I. Reichle, S. Siegel, \& A. Spelten (Eds.), Visuelle Modelle (pp. 71-84). München: Fink.

Schlechtriemen, T. (2012, October). Das Bild des Netzwerks und seine Rolle in der soziologischen Theoriebildung. Ad-Hoc-Gruppe "Metaphern der Gesellschaft", Bochum. 
Secord, J. A. (2004). Knowledge in transit: Halifax Keynote Address. Isis, 95(4), 654-672.

Scott, J. W. (2002). Feminist reverberations. differences: A Journal of Feminist Cultural Studies, 13(3), $1-23$.

Shinn, T., \& Whitley, R. P. (Eds.). (1985). Sociology of the sciences: Vol. 9. Expository science: Forms and functions of popularisation. Dordrecht: Reidel.

Smejkalova, J. (1995). On the Road: Smuggling Feminism Across the Post-Iron Curtain. Replika, (1), 97-102. Retrieved from http://www.c3.hu/scripta/scripta0/replika/honlap/english/01/10fsmej.htm

Sousa Santos, Boaventura de. (2005). The future of the World Social Forum: the work of translation. Development in Practice, 48(2), 15-22.

Steinmetz, G. (2006). Decolonizing German theory: an introduction. Postcolonial Studies, 9(1), 3-13.

Stengers, I. (Ed.). (1987). D'une science à l'autre: Des concepts nomades. Paris: Éd. du Seuil.

Tsing, A. (2000). The Global Situation. Cultural Anthropology, 15(3), 327-360.

Wickson, F., Carew, A. L., \& Russell, A. W. (2006). Transdisciplinary research: characteristics, quandries and quality. Futures, 38, 1046-1059.

Wöhrer, V. Gender Studies as a Multi-Centered Field? Centers and Peripheries in Academic Gender Research. Women's Studies International Forum, submitted.

Zimmerman, A. (2006). Decolonizing Weber. Postcolonial Studies, 9(1), 53-79. 